\title{
Lost and found in translation: the case of alliteration
}

\author{
Mihhail Lotman, Maria-Kristiina Lotman*
}

\begin{abstract}
The paper examines the transmission of alliteration in Estonian and Russian translated verse. The main focus is on the translation of alliterative epic, on the one hand, and more recent literary alliteration, on the other hand. Various alliterative techniques in different genres are observed, as well as various strategies in conveying alliteration: rejection of alliteration, transmission of alliteration, compensatory translation, for example, with functional equivalent and eventually, saturation with alliteration, to signal alliteration in a tradition without corresponding framework.
\end{abstract}

Key words: alliteration, metrics, parallelism, poetry translation, sound repetitions

\section{Introductory remarks}

An important issue in poetry translation is the transmission of alliteration. The difficulty lies not only in linguistic differences (for instance, vocalic and consonantal languages, languages with fixed and variable stress, languages with and without quantity contrast), but also in different poetry traditions: the forms and treatments of alliteration may be rather different in various poetic systems.

Alliteration is a widely spread phenomenon in different verse cultures, yet already the term itself is ambiguous and comprises phenomena distinct in principle. In the broadest meaning, alliteration is a form of instrumentation which lies in the repetition of sounds, while these sounds are not necessarily just consonants. In a more narrow sense, we are dealing with the repetition of consonants, with further differentiation depending on if this repetition has a purely euphonic or also a metrical role. In this sense, the most rigorous alliteration is the repetition of consonants in the so-called alliterative verse, of which the most well-described is the Germanic verse, but the alliterative verse has also been discussed in correlation with different Uralic languages.

* Authors' addresses: Mihhail Lotman, Department of Semiotics, University of Tartu, Jakobi 2, 51014 Tartu, Estonia, e-mail: mihhail@ehi.ee; Maria-Kristiina Lotman, Department of Classical Philology, University of Tartu, Ülikooli 17, 51014 Tartu, Estonia. E-mail: maria.lotman@mail.ee. 
The following typology can be offered proceeding from the strictness of the function of alliteration in verse:

1. Alliteration which marks strong metrical positions within the verse line. Such is alliteration in Germanic alliterative verse, where different models of alliteration are represented, but in every hemistich (German Kurzzeile) at least one alliterative word is present, while the most common model is where two alliterating words are in the first half verse, one in another, that is, aa/a (see, for instance, Smirnitskaya 1994, Terasawa 2011). Conditionally, we will call such alliteration "the Germanic type".

2. Alliteration in the Finnic folk verse (Estonian regisong, Finnish kalevalamitta), where alliteration is mandatory (Finnish) or almost mandatory (Estonian), but its positions in verse are not fixed. In Estonian, such alliteration is usually called the initial rhyme (algriim; in Finnish tradition, alkusointu). Differently from the first type, this alliteration is not related to the internal structure of verse, but characterises verse as a whole. Conditionally, we will call such alliteration technique "the Finnic type". See also Laugaste 1962, 1969; Leino 1970; Kuusi 1953, Roper 2009, Frog, Stepanova 2011.

3. In different Altaic languages alliteration connects the beginnings of verse, and is called vertical alliteration or line-initial alliteration (Zhirmunsky 1968: 36; see also Petrov 1990). Such alliteration has a function similar to that of rhyme, yet it does not mark the end of a verse line, but its beginning. Vertical alliteration can connect two consecutive verses, but such sequence can also be formed with tens of verses. Conditionally, we will call such alliteration "the Altaic type".

4. A consonantal repetition of sounds, which does not necessarily have a metrical role, is also called alliteration. Conditionally, we will call it modern alliteration. Here we would like to emphasise the conventionality of these designations. For instance, if we call this type modern, it means that it is the most common type of alliteration in a particular verse culture, but not that it evolved only recently. The same type of alliteration can be seen also in most different archaic cultures. See, for instance, Ellinger 1938, Langer 1978.

In our paper we will bring some examples of alliteration technique, focusing mainly on the first and the fourth types; however, in relation with Kalevala and its translation, we will put emphasis on the second type, too. As for the third type, here we have not conducted a special analysis and we would want 
to only point out some problems, since in a way it is the most enigmatic type of alliteration. It can be clearly seen in a printed text, but it evolved in oral performance, while in literary poetry it appears mainly as imitations. At the same time, this technique is quite widespread in different languages of the Altaic language family. In such a large geographical area, and in the case of such cultures, it is often problematic to establish their actual contact, not to speak of derivation from one and the same source. Nevertheless, we would like to draw attention to one circumstance related to vertical alliteration; it is present in cultures which have or have had a practice of throat singing, while this singing technique is connected to epic verse with vertical alliteration. In some Tungusic languages, this technique has been called toyuk and is not as much connected with epic, but with greeting songs. In Turkic people, beginning with Yakuts in North-East, ending with Kyrgyz people in the South-East, it is called kai (qai), and kai singers are called kaichi. Just like toyuk, kai is prevailingly 8-syllabic and alliterative (compare also Levin, Edgerton 1999 and Harvilahti 2000).

Let us offer a few examples. The first is from a modern Evenki poem, which imitates the archaic style; compare the beginning of the chain consisting of twenty nine verses:

\begin{tabular}{|c|c|}
\hline Evenks' toyuk To Tuymaada toyuk-singers ${ }^{1}$ & Transliteration \\
\hline $\begin{array}{l}\text { Tуймаадам туонатыгар } \\
\text { Tойук туммсуу дьонноро, } \\
\text { Tуойан ыллаан ааЇабыт. } \\
\text { Tойук, ўнкўу дьонноро, } \\
\text { Tомтор, кырдал сирдэргэ } \\
\text { TоіуоруЇан тураммыт, } \\
\text { Tумул, алаас аайытын, } \\
\text { Tохтоон тойук туойабыт. }\end{array}$ & 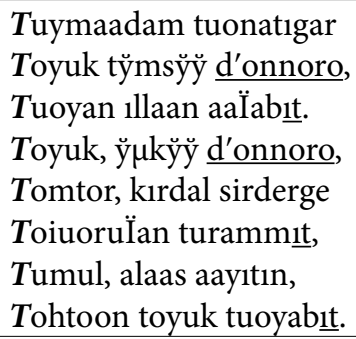 \\
\hline
\end{tabular}

We were not able to find a poetic translation of it, but the content is as follows: in the happy valley of Tuymaada toyuk has united us all, on every hill, on every meadow we have gathered to sing toyuk.

The second example is from the introduction (zhomok bashy) to Kyrgyz Epic of Manas:

2 Here and henceforth, alliterations are marked with italics, rhymes and epiphoras are underlined. 


\begin{tabular}{|c|c|}
\hline Kyrgyz Epic of Manas & Transliteration \\
\hline 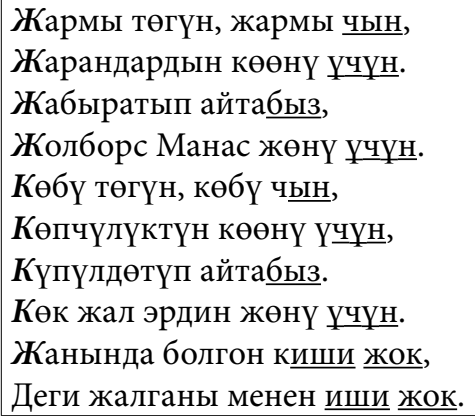 & $\begin{array}{l}\text { Jarmı tögün, jarmı çın, } \\
\text { Jarandardın köönü üçün. } \\
\text { Jabıratıp aytabız, } \\
\text { Jolbors Manas jönü üçün. } \\
\text { Köbü tögün, köbü çın, } \\
\text { Köpçülüktün köönü üçün, } \\
\text { Küpüldötüp aytabız. } \\
\text { Kök jal erdin jönü üçün. } \\
\text { Janında bolgon kiși jok, } \\
\text { Degi jalganı menen } \underline{\text { iși jok. }} \text {. }\end{array}$ \\
\hline
\end{tabular}

Differently from toyuk, Manas is characterised not just with vertical alliteration, but with grammatical rhyme together with the syntactic parallelism. In Russian translations, one translator has conveyed just the resonance of the ending, while the vertical alliteration is absent, the other, on the contrary, has conveyed the vertical alliteration without the resonance of the endings.

First, the version by Mar Baidjiev, who has focused on end rhymes (although these too are rather episodic).

\begin{tabular}{|l|l|}
\hline Куrgyz Epic of Manas, translated by Mar Baidjiev & Transliteration \\
\hline А самым младшим был Ногой. & A samym mladshim byl Nogoj. \\
Усен, Орозду, Бай, & Usen, Orozdu, Baj, \\
Жакып - от Ногой-хана сыновья. & Zhakyp - ot Nogoj-hana synov'ja. \\
Могучим ханом был Ногой. & Moguchim hanom byl Nogoj. \\
За свой народ и край родной & Za svoj narod i kraj rodnoj \\
Не раз вступал в кровавый бой. & Ne raz vstupal v krovavyj boj. \\
Китайцам и монголам он & Kitajcam i mongolam on \\
В набегах учинял разгром. & V nabegah uchinjal razgrom. \\
\hline
\end{tabular}

Differently from Baidjiev, Lev Penkovsky aims to convey vertical alliteration, the most important feature of instrumentation here:

\begin{tabular}{|l|l|}
\hline $\begin{array}{l}\text { Kyrgyz Epic of Manas, } \\
\text { translated by Lev Penkovsky }\end{array}$ & Transliteration \\
\hline Кучами золото мы гребли, & Кисhami zoloto my grebli, \\
Куньи шапки были на нас, & К $\boldsymbol{u}$ n'i shapki byli na nas, \\
Кушак из шёлка носили мы, & $\boldsymbol{K}$ shak iz sholka nosili my, \\
Кушали вкусные курдюки, & Kushali vkusnye kurdjuki, \\
\hline
\end{tabular}


There has been much discussion regarding the relations of alliteration with other prosodic elements both from the aspect of versification and structure of language. Victor Zhirmunsky, who studied the folk poetry of different Altaic nations, noted the regularity how alliteration is related to syntactic parallelism, and that corresponding languages have a weak dynamic accent, which is usually fixed to the end of a word or a syntagm (Zhirmunsky 1964, 1968, 1974; Stebleva 1965, 1971; correlations between parallelism and alliteration can be observed in other traditions as well, for instance, Finnic, compare Steinitz 1934). As for European, first of all, Germanic verse, it is, to the contrary, usually associated with strong dynamic accent, which is typically on the initial syllable of the word. To a certain extent it can also explain the alliteration in the Finnic verse, although the accent here is not strong but is fixed to the beginning of word. According to Eduard Sievers and Winfred P. Lehmann (Sievers 1893; Lehmann 1956, 1972), the alliterative verse is not as much related to accent, but to quantity (see also Kuryłowicz 1949, 1970, 1975: 150-153). The alliterative Germanic verse was not purely accentual, but in our terminology accentualsyllabic-quantitative (Lotman 1998: 2064). When quantity disappeared from language as well as from verse as a rhythmic factor, alliteration disappeared too and was replaced with end rhyme. In a way, analogical processes can be observed in the development of Estonian folk verse as well, where, together with the increase of accentual factor, alliteration had disappeared and end rhymed evolved (so-called vemmalvärss, that is, doggerel verse).

In our paper we will bring some examples about the use of alliteration in two traditions which are different in principle: Russian and Estonian.

The Estonian language has all preconditions for the formation of alliterative tradition: quantitative - the contrast of quantity in langugage, allowing for the quantitative principle in verse; accentual - the fixed accent in the first syllable of a word; and, morphonological - the lack of prefixes, which means that the normal Estonian word begins with a stem with accent on its first syllable. Thus, it seems natural that in the Estonian folk song tradition, alliterative verse plays a significant part.

In Russian language, on the other hand, the contrast of quantity is absent (accentual syllables are one and a half times longer than unaccented syllables, but it is merely a phonetic, but not a phonological phenomenon). The position of accent is free, and regulated only by statistical regularities, according to which it has a tendency to be placed in the central position of a word. From the aspect of morphonology it is important to note that Russian has a welldeveloped system of prefixes, so a large portion of words begins with prefixes, not with stem alone (while due to the free position of accent, the stem does not necessarily carry a stress). As a result of all this, there is no alliterative verse in 
Russian folk tradition (although there is sporadic use of alliteration, compare Čiževsky 1949); instead, there are other phonic devices, for instance, paronymy and episodic rhyme. Also, "Russian ear" is less sensitive to alliteration.

Alliteration in Russian poetry tradition is mostly a local gesture, and not a constant principle. In order to be noticed, it needs to be more intensive, for instance, in Konstantin Balmont's widely anthologised example:

\begin{tabular}{|l|l|}
\hline Konstantin Balmont's “I am free wind...” & Transliteration \\
\hline Я вольный ветер, я вечно вею, & Ja vol'nyj veter, ja vechno veju, \\
Волную волны, ласкаю ивы, & Volnuju $\boldsymbol{v o l n y , ~ l a s k a j u ~ i v y , ~}$ \\
В ветвях вздыхаю, вздохнув, немею, & V vetvjah $v$ zdykhaju, vzdokhnuv, nemeju, \\
Лелею травы, лелею нивы. & Leleju travy, leleju nivy. \\
\hline
\end{tabular}

Another aspect, which is represented in the same example, is how Russian alliterative technique is more sensitive to onomatopoeia.

\begin{tabular}{|c|c|}
\hline Konstantin Balmont's Reeds & Transliteration \\
\hline 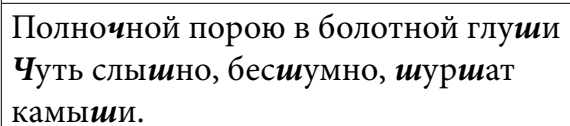 & $\begin{array}{l}\text { Polnochnoj poroju v bolotnoj glush } \\
\text { Chut' slyshno, besshumno, shurshat } \\
\text { kamyshi. }\end{array}$ \\
\hline
\end{tabular}

In these examples we can see it in wind-blasts, which is conveyed with the repetition of 've/vu', as well as in its purely synesthetically transmitted tenderness: 'la/le', and 'sh/s', which stand for whispers (in the second example, 'sh' conveys the sound of swishing reeds). Sometimes we come across the opposition of two alliterations on the phonetic as well as the semantic level, see the fragment from Pushkin's Eugene Onegin:

\begin{tabular}{|c|c|}
\hline Pushkin's Eugene Onegin (5, XLII): & Transliteration \\
\hline $\begin{array}{l}\text { Мазурка раздалась. Бывало, } \\
\text { Когда гремел мазурки гром, } \\
\text { В огромной зале все дрожало, } \\
\text { Паркет трещал под каблуком, } \\
\text { Тряслися, дребезжали рамы; } \\
\text { Теперь не то: и мьь, как дамы, } \\
\text { Скользим по лаковым доскам. }\end{array}$ & $\begin{array}{l}\text { Mazurka razdalas'. Byvalo, } \\
\text { Kogda gremel mazurki } \text { grom, } \\
\text { V ogromnoj zale vse } \boldsymbol{d} \text { rozhalo, } \\
\text { Parket } \text { treshhal pod kablukom, } \\
\text { Trjaslisja, drebezzhali ramy; } \\
\text { Teper' ne to: i } \boldsymbol{m} \boldsymbol{y} \text {, kak damy, } \\
\text { Skol'zim po lakovym doskam. }\end{array}$ \\
\hline
\end{tabular}

In this passage the old, that is, the right and proper mazurka dance, is opposed to the corrupted modern one. The old is connected with the emphasised masculinity and noise, while the modern with feminine tender fluency; 
furthermore, the femininity is brought in on a semantic level just with a comparison: we (that is, men) glide like ladies. Out of seven lines, five are devoted to the old, which are accompanied by the alliterations 'gr', 'dr', 'tr', 'r', while the two last "feminine" verses are instrumentally delivered with 'l' and ' $m$ '. Psycholinguistic studies reveal that for the carriers of Russian language ' $\mathrm{g}$ ' and ' $r$ ', and especially their composites, are sensed as agressive (one has to keep in mind that Russian ' $r$ ' sounds much more aggressive than the English ' $r$ '), but 'l' and ' $m$ ' are recognised as tender (Taranovsky 1965a, 1965b).

\section{Alliteration in translation}

Eugene Onegin has been repeatedly translated into English, but none of the translators has been able to convey Pushkin's instrumentation. We will bring just one example:

Now the mazurka sounds. Its thunder used in times past to ring a peal that huge ballrooms vibrated under, while floors would split from crash of heel, and frames would shudder, windows tremble; now things are changed, now we resemble ladies who glide on waxed parquet.

(Alexandr Pushkin's Eugene Onegin 5, XLII, translated by Charles H. Johnston)

Let us just make a brief comment on the differences between the original text and the translation. The translator did not convey the onomatopoetic alliteration of the source text, the noisy masculinity of the first part is conveyed only by lexical means (using onomatopoetic words like 'crash', 'shudden', 'tremble'), but in the last two lines the feminine fluency is supported with phonic means.

\section{Raven, kaaren and voron}

It is especially enlightening to study alliteration in translated texts, and in particular when we are dealing with different language and cultural types. Let us bring an example from literary texts, that is Edgar Allan Poe's Raven, which is known for the abundance of its alliterations as well as its onomatopoetic effects. If we take a look at the English original, then, roughly speaking, the 
sound gestures serve two ideas. First and foremost, the idea is a recurrent theme of hopelessness, fate and death, which both semantically and euphonically culminate in the word nevermore. But on the phonic level, preparations for it start from the beginning of the poem, and primarily in its rhymes: 'lore', 'door', 'more', 'floor', and so on. What is very important in this context, is, first, how the name of the dead beloved Lenore belongs to the same phonic sphere, and second, that the title of the poem, Raven, is an almost precise anagram of the word 'never', even closer acoustically than visually. The second, semantic as well as phonic pole of the poem builds the fears and sensations of the first person character, and we are dealing here with different phonetic themes constructed not as much in rhyme, as they are in alliteration. The rhythmicalsyntactical structure of the poem clearly serves the same purposes: on the one hand, repetitions create the magical effect, in keeping with the themes of hopelessness and fate, on the other hand, the hesitant feelings embodied, relate to the inner world of the narrator. To compare different translation strategies, we extracted the first three stanzas both from the source text and the target texts. The beginning of Poe's original text is here:

Once upon a midnight dreary, while I pondered weak and weary, Over many a quaint and curious volume of forgotten lore, While I nodded, nearly $n$ apping, suddenly there came a tapping, As of some one gently rapping, rapping at my chamber door. "Tis some visitor,' I muttered, 'tapping at my chamber door Only this, and nothing more.'

Ah, distinctly I remember it was in the bleak December, And each separate dying ember wrought its ghost upon the floor. Eagerly I wished the morrow; - vainly I had sought to borrow From my books surcease of sorrow - sorrow for the lost Lenore For the rare and radiant maiden whom the angels named Lenore Nameless here for evermore.

And the silken sad uncertain rustling of each purple curtain Thrilled me - filled me with fantastic terrors never felt before; So that now, to still the beating of my heart, I stood repeating "Tis some visitor entreating entrance at my chamber door Some late visitor entreating entrance at my chamber door; This it is, and nothing more,' 
Let us compare the Estonian translations. The first translator of Raven was Ants Oras, a literary scholar, critic and translator, who first published his translation of Poe's poem in 1929, with a revised version in 1931, where he had increased the incidence of alliterations and other sound repetitions, as evidenced in his first three stanzas:

Südaööl, mil kambris selles $t u$ mmalt, $\boldsymbol{t} u$ skjalt mõlgutelles

Meeliskelin aegu vanu, ammu veernuid surmani,

Kuulin äkitselt eel ukse kerge väikse sõrmetukse,

Koputuse ma eel ukse, tasa kostva minuni.

"Rändur see vist rännukäigul, jõudev öisel minuni,"

mõtlin, "Muud ei midagi."

Talv too oli, öö, mil ahi nagu tukkuv tulikahi pidas viirastava $\boldsymbol{v a h i}$ - valvur öise helvetí!

Tusklin ja all paatund koore hõõgus vaev mul imme noore,

Neitsi pärast kel Lenoore nimeks nüüd ja alati -

nimi nii kesk inglikoore taevas nüüd ja alati sääl vaid - siin ei iialgi.

Kuulin, $\boldsymbol{k u u l e n}$ veel, $\boldsymbol{k}$ uis $\underline{\boldsymbol{k} \text { ahin, }}$, siidi hiiliv salas $\underline{\text { ahin }}$ esiriideist käib, ja vaatan, hurmund, hirmund surmani, nii et, võites õudse põkse rinnas mu, peaaegu rõkk see huulilt kuuldub: "Ei, ei, lôkse Saatan sea. See vihuti hirm, see rändur vaid, kuis ikka otsiv paika öösiti rändur vaid - muud midagi."

(Edgar Allan Poe's Kaaren, translated by Ants Oras)

Ants Oras follows the stanzaic structure as well as the rhyme pattern of the source text. Although in his text overall inflectional rhymes prevail, he retains Lenore's name in rhyme position. Alliteration, sound plays and repetitions are consistently conveyed, yet his alliterations are more emphasised and stronger; they are often not just confined to the initial consonants, but comprise the vowel of an initial syllable as well. Sometimes it is also a result of a repetition of a stem, like, for instance, in the 5th stanza: 'vaatlin, $\boldsymbol{m} \tilde{\boldsymbol{o} t}$ lin $\boldsymbol{m} \tilde{\boldsymbol{o}} \boldsymbol{t t e i d}$ kurbi, mõtteid, mõeld ei iialgi. On the phonic level, the motif of "hiss" is introduced already in the second stanza in the rhyming triplet: 'ahi/kahi/vahi'. In the third stanza, a rhyme with the same sound is continued ('kahin/sahin'), and is supported with s- and h-alliterations. 
A year later Johannes Aavik, a philologist, translator and neologist, who was even more radical than Oras in his innovations both in the sphere of language and poetry, published his polemical version of the poem. His polemic begins already with the title: the name of the bird can be in Estonian either 'ronk' or 'kaaren'. The second was used by Oras, while Aavik, on the other hand, chose the first, despite 'kaaren' being phonetically closer to 'raven'.

Let us see the first three stanzas of Aavik's translation:

Keset öise tunni õudu kord ma juurdlin, roidund, nõutu

vana tarkusteose kallal, mis ju unund ammugi.

Olin tukkumas, $\boldsymbol{k}$ ui $\boldsymbol{k} \underline{\text { abin }} \boldsymbol{k}$ õlas just $\boldsymbol{k u i} \boldsymbol{s a m m e} \boldsymbol{s} \underline{\mathrm{abin}}$

või kui mingi arglik rabin vastu ust nii äkisti.

Vist üks väisur, mõtlin, kabin sellest vistist' sünniblki, -

see - ja muud ei midagi.

Käes siis oli algav tali, väljas mühas tuul nii vali

koldes $\boldsymbol{k u ̈ d e s}$ kustuv tuli, heitis varje viiliti.

Hommikut ma kangest' ootsin; - raamatuist, mil vaimu jootsin,

asjata ma troosti lootsin, sest mu armsaim võeti -

hurmav neid, Leonoore nimeks ingliten kel' anneti -

siin tal nime polegi.

Ukserimba siidi sahin, purpurkatte vaikne $\boldsymbol{k a h i n}$

äratas mus õudset hirmu, enne tunt ei iialgi,

ning mu süda põksus nõnda, et siis mina korda mõnda

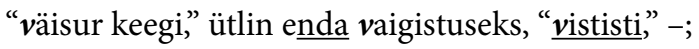

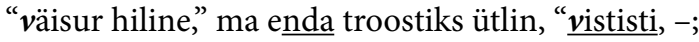

see - ja muud ei midagi."

(Edgar Allan Poe's Ronk, translated by Johannes Aavik, 1930)

Johannes Aavik has conveyed the rhyme scheme, but in the case of masculine rhymes he has given up the lexical rhymes in favour of the inflectional rhyme; consequently, when compared to the source text, these rhymes are phonically more fragile and semantically less loaded. Feminine rhymes, on the other hand, are lexical and the internal rhymes have also been conveyed. Yet it has to be mentioned that in the original text the masculine rhymes are especially important from the viewpoint of semantics of the text.

For Aavik, alliteration is not insignificant either. Although he has not found a possibility to convey these in the first line of a poem, there are still numerous 
alliterative couplets or triplets (for instance, 'tarkusteose', which is a compound word, 'kui/kabin/kõlas', 'samme/sabin', and so on). It has to be noted that Aavik sensed the two contrasting themes on the phonic level of the original: the first is related to raven, the other to the sensations of the first person character. In the transmission of these, Aavik uses both alliterative and onomatopoetic technique. Thus, already in the first stanza, the theme of raven occurs as an onomatopoetic alliteration ' $k$ ui $\boldsymbol{k}$ abin $\boldsymbol{k}$ õlas just $\boldsymbol{k} \boldsymbol{u} \boldsymbol{i}$ ', as well as an onomatopoetic word pair 'rabin/kabin', where an anagramm of raven can be sensed as well. At the same time, in the third stanza, the alliteration of 's', and the following onomatopoetic rhymes, create the atmosphere of whispers and silent hiss.

This poem has been translated into Russian language many times, with about ten famous renditions. It was especially popular among the symbolists, and has been translated by such leading figures of symbolism as Dmitry Merezhkovsky, Konstantin Balmont and Valery Bryusov. These, as well as later authors, attempted to convey the meter, as well as the rhyme scheme and phonic structure. Yet, differently from the Estonian authors, the Russian poets were not able to convey the recurrent masculine rhyme, excluding just one exception. Vasily Betaki, a poet from the next generation (who had passed away in 2013), in his time won a competition as best translator of Edgar Allan Poe (compare Friedberg 1997: 119-120). However, his version has not been as well-known as the symbolist translations. We will briefly focus on the most famous ones, the translations by Konstantin Balmont and Valery Bryusov, and will add to it Altalena's ${ }^{1}$ version, who according to experts Nina Berberova and Mikhail Gasparov is superior to those of Balmont and Bryusov².

Как-то в полночь, в час угрюмый, полный тягостною думой,

Над старинными томами я склонялся в полусне,

Грёзам странным отдавался, вдруг неясный звук раздался,

Будто кто-то постучался - постучался в дверь ко ме․

“Это верно”, прошептал я, "гость в полночной тишине,

Гость стучится в дверь ко мнё.

Ясно помню... Ожиданья... Поздней осени рыданья...

И в камине очертанья тускло тлеющих углей...

$\mathrm{O}$, как жаждал я рассвета, как я тщётно ждал ответа

На страданье, без привета, на вопрос о ней, о ней,

1 Altalena (italian 'swing') was Vladimir Zhabotinsky's (Ze’ev Jabotinsky's) pseudonym.

2 See addendum for transliterations. 
О Леноре, что блистала ярче всех земных огней,

О светиле прежних дней.

И завес пурпурных трепет издавал как будто лепет,

Трепет, лепет, наполнявший тёмным чувством сердце мне.

Непонятный страх смиряя, встал я с места, повторяя: -

“Это только гость, блуждая, постучался в дверь ко мее,

Поздний гость приюта просит в полуночной тишине -

Гость стучится в дверь ко мне”.

(Edgar Allan Poe's Voron, translated by Konstantin Balmont, 1894)

Как-то в полночь, утомлённый, я забылся, полусонный, Над таинственным значеньем фолианта одного; Я дремал, и всё молчало... Что-то тихо прозвучало Что-то тихо застучало у порога моего.

Я подумал: “То стучится гость у входа моего -

Гость, и больше ничего”.

Помню всё, как это было: мрак - декабрь - ненастье выло Гас очаг мой - так уныло падал отблеск от него...

Не светало... Что за муки! Не могла мне глубь науки Дать забвенье о разлуке с девой сердца моего, О Леноре, взятой в Небо прочь из дома моего, Не оставив ничего...

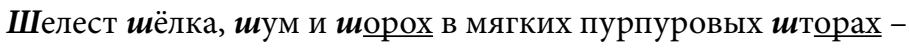
Чуткой, жуткой, странной дрожью проникал меня всего; И, смиряя страх минутный, я шепнул в тревоге смутной:

“То стучится бесприютный гость у входа моего -

Поздний путник там стучится у порога моего Гость, и больше ничего”.

(Edgar Allan Poe's Voron, translated by Altalena, 1897)

Как-то в полночь, в час унылый, я вникал, устав, без силы, Меж томов старинных, в строки рассужденья одного По отвергнутой науке, и расслышал смутно звуки, Вдруг у двери словно стуки, - стук у входа моего. “Это - гость, - пробормотал я, - там, у входа моего. Гость, - и больше ничего!" 
Ax! мне помнится так ясно: был декабрь и день ненастный, Был как призрак - отсвет красный от камина моего. Ждал зари я в нетерпеньи, в книгах тщетно утешенье Я искал в ту ночь мученья, - бденья ночь, без той, кого Звали здесь Линор. То имя... Шепчут ангелы его, На земле же - нет ег्.

Шелковистый и не резкий, шорох алой занавески Мучил, полнил темным страхом, что не знал я до того. Чтоб смирить в себе биенья сердца, долго в утешенье Я твердил: “То - посещенье просто друга одного.” Повторял: “То - посещенье просто друга одного, Друга, - больше ничего!”

(Edgar Allan Poe's Voron, translated by Valery Bryusov, 1905)

As we have already mentioned, the specifics of Russian language did not allow for the development of such alliterative technique which can be seen in Finnic and Germanic folklore, and in literary texts, repetition of sounds has to be more intense to be perceived. We have marked the repetitions of consonants, but differently from rhyme they do not constitute an important aesthetic factor. In order to highlight the phonics, the authors use either a rhyme-like instrumentation in places not meant for it, like, for instance, 'Трепет, лепет' in Balmont, or paronymy or repetitions of syllables, like, for example, 'полночь, полный' also in Balmont. From the aspect of alliterations, the most effective is Altalena's translation. Compare the first line in his third stanza, where the sound 'sh' is repeated and it has a strong onomatopoetic effect: hiss or rustle. Yet, as we see in the case of the Estonian translators, in Russian translations too the main sound theme related to fate, death and Lenore is overshadowed by local gestures.

\section{Translations of alliterative epic}

Russian translations of Kalevala (there are two widespread full translations, the older is by Leonid Belsky, the modern by Eino Kiuru and Armas Mishin) are semantically quite close to the original. From the artistic point of view we should prefer the first, but the new one is in a way more punctual. Yet neither of these conveys the alliterative technique of the source text, and where alliteration appears in its modern type, it is not as a mandatory factor characterising 
every verse. However, in both translations we come across not just local alliterations, but also phonemic symploces ${ }^{3}$ and paronymies.

As for the Germanic alliterative verse, the Russian translators have not paid much attention to alliteration, focusing on the transmission of content and verse meter. Yet the first attempt of translating the Elder Edda deserves to be mentioned. The translator was Alexandr Vostokov, who conveyed it not in the original meter, but in the epic Slavic verse, which he had reconstructed. There are two reasons why the alliteration was not conveyed. First, as we already mentioned, the repetition of single word-initial consonants is not as clearly perceived as in the case of Germanic languages. The other reason is related to content. The Elder Edda, and Beowulf as well, were seen not only as works of art, but also as sources of history, which was to be conveyed as punctually as possible. So it is characteristic that Skaldic poetry, the structure of which is much more complicated than that of Elder Edda, is translated closely following the form, and conveying rhymes as well as alliterations.

As for the Estonian translations of alliterative epics, we have studied three more important translations, that of Kalevala translated by August Annist, and Beowulf and Elder Edda by Rein Sepp ${ }^{4}$. Alliteration is a significant factor of versification in these texts: both in the samples from Beowulf and Elder Edda verses without at least one alliterating pair were quite exceptional, such were not much more than $5 \%$ of the total sample. At the same time there were also alliterating quadruplets and verses combined of two alliterating triplets, or of one triplet and one quadruple, see, for instance, an example from Beowulf:

kes $\boldsymbol{v} \tilde{\boldsymbol{o}}$ tta $\boldsymbol{v} \tilde{\boldsymbol{o i s}} \boldsymbol{v}$ astu $\boldsymbol{k}$ ord $\boldsymbol{v}$ oogude $\boldsymbol{k a n d a m i . ~ ( 1 . 5 2 ) ~}$

Let us compare the chart showing the most common patterns of alliteration in these translations:

3 Phonemic symploce is a repetitive phonemic complex. It differs from alliteration and assonance in having both consonants and vowels in its formation, from paronymy in that there is no concomitant illusions of morphemic repetitions (Lotman, Nakhimovsky 1971). For instance, rare and radiant, vaovad hammasta vahele.

4 This is a pilot study to find out the most common patterns and regularities in the Estonian translations of alliterative verse. Each sample consists of 100 verses; full-scale studies should be pursued in the future. 


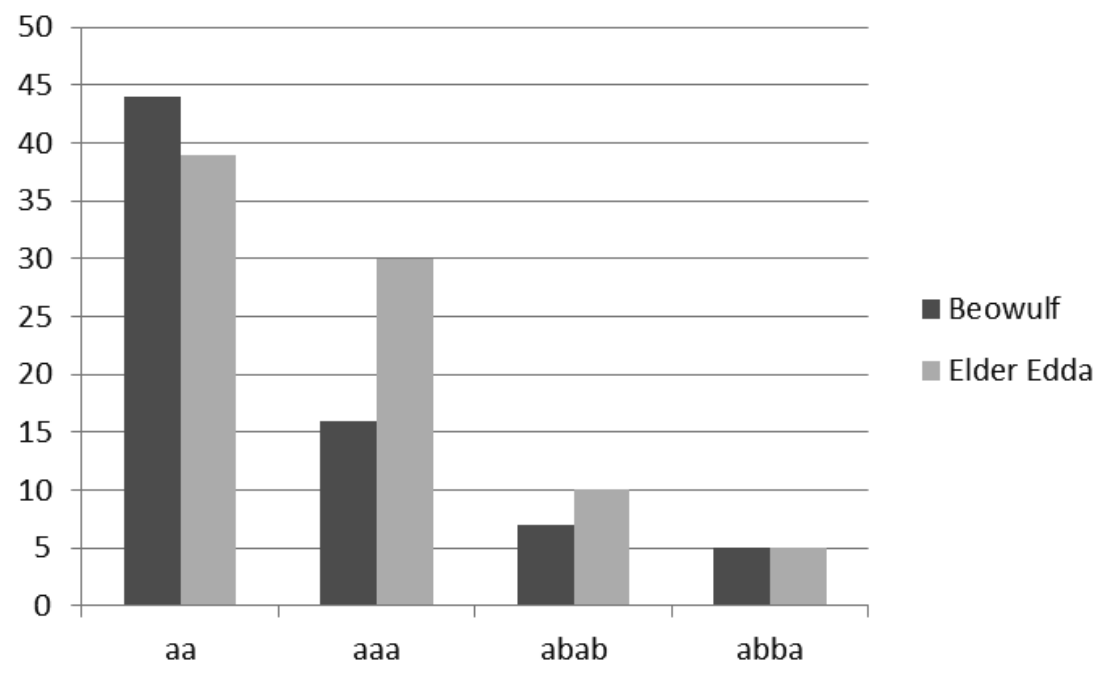

Chart 1. Common alliteration patterns in Estonian translations of Beowulfand Elder Edda.

This reveals that the most frequent pattern both in Beowulf and Elder Edda is one alliterating pair per verse line: such lines comprise about $40 \%$ of the samples. Alliterating triplets are the second most frequent pattern (reaching to $30 \%$ in the Elder Edda). And, there are also some combinations of different sounds in alliteration.

Kalevala is a bit more complicated case: in the canonic Estonian edition, two trochaic tetrameters are typographically united into one verse line. It is not, however, a translator's decision, as the author of the afterword, Heldur Niit, explained the necessity of such typographical solution with the readability of the text, following the 1949 Finnish edition of Kalevala (edited by Jouko Hautala).

Let us see the first lines:

Mõtleb nüüd $\boldsymbol{m u}$ meelekene, $\boldsymbol{a j u d}$ need $\boldsymbol{a r u}$ peavad, meel see lükkab laulemaie, suu $k$ utsub $k$ õnelemaie, põlist laulu leelutama, lugu pikkada laduma.

Sõnad suussa $\boldsymbol{m u l}$ sulavad, $k$ õned muistsed $k$ eerutavad, ise keelele ronivad, $\boldsymbol{v a}$ ovad hammasta $\boldsymbol{v} \boldsymbol{a}$ hele.

When we look at the two half lines separately, we see that about $8 \%$ of these are without alliterations (as in the first half verse of the last line in the given example). But if we consider these together, then verses without alliterations are extremely rare (there was just one case in our sample). In the following chart you can see the most common patterns in the translation of Kalevala: 


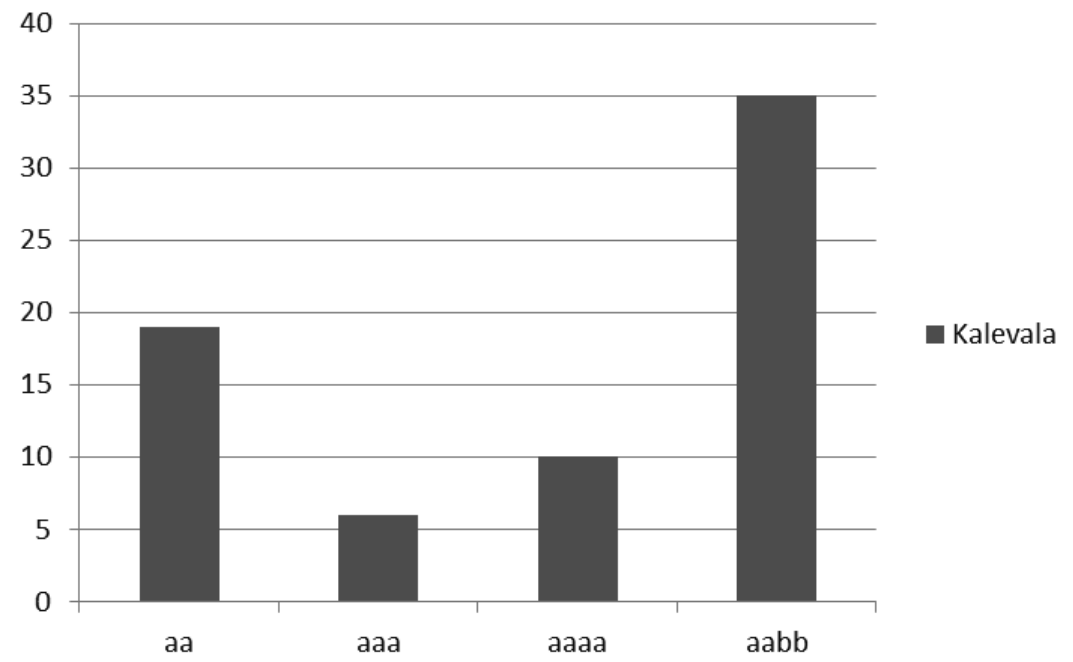

Chart 2. Common alliteration patterns in Estonian translation of Kalevala.

In Kalevala we come across the combination of two alliterating pairs, most frequently the second place is held by verses with an alliterating pair. But if we examine these verses more closely we can see alliterating pairs prevail in one half-verse line, while there is no alliteration in the other one, like in this verse:

neid mu õpetas emake veeretelles värtenada,

This means that although typographically the two verses are united, on the phonic level these are still separate units and alliteration does not tie them together, as compared to the translations of Germanic verse, such patterns where two alliterating pairs are crossed or interlocking are rarer. Yet we can sometimes see the repetition of one and the same sound through several halflines and even verses, like in the following example:

kui olin poisike põrandal, püherdelin põlvi eessa

piimalutt-pisikesena, piimasuise põngerjana.

In the next chart we can see the data about the incidence of alliterating sounds in the studied samples, here the ratio of alliterating sounds is compared to the total number of characters: 


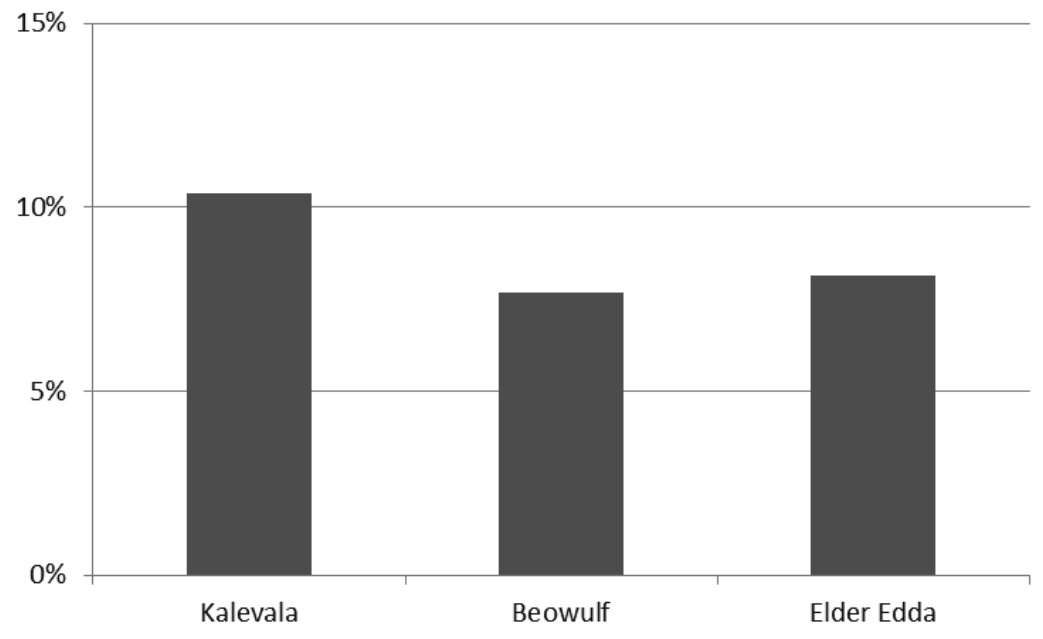

Chart 3. Incidence of alliterating sounds in Estonian translations of alliterative epic.

The highest incidence of alliterating sounds is in the translation of Kalevala, where this ratio exceeds $10 \%$, meanwhile in the translations of Germanic epics it is about $8 \%$. The statistic representation of different sounds is presented on the following charts:

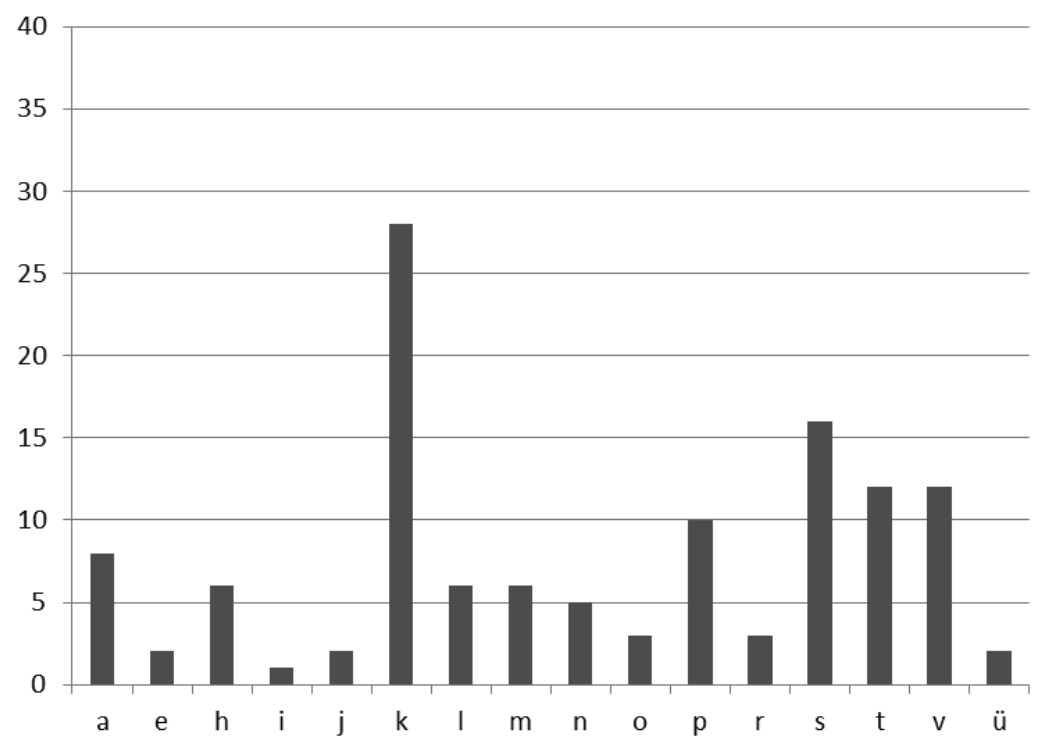

Chart 4. Different sounds in Estonian translation of Beowulf. 


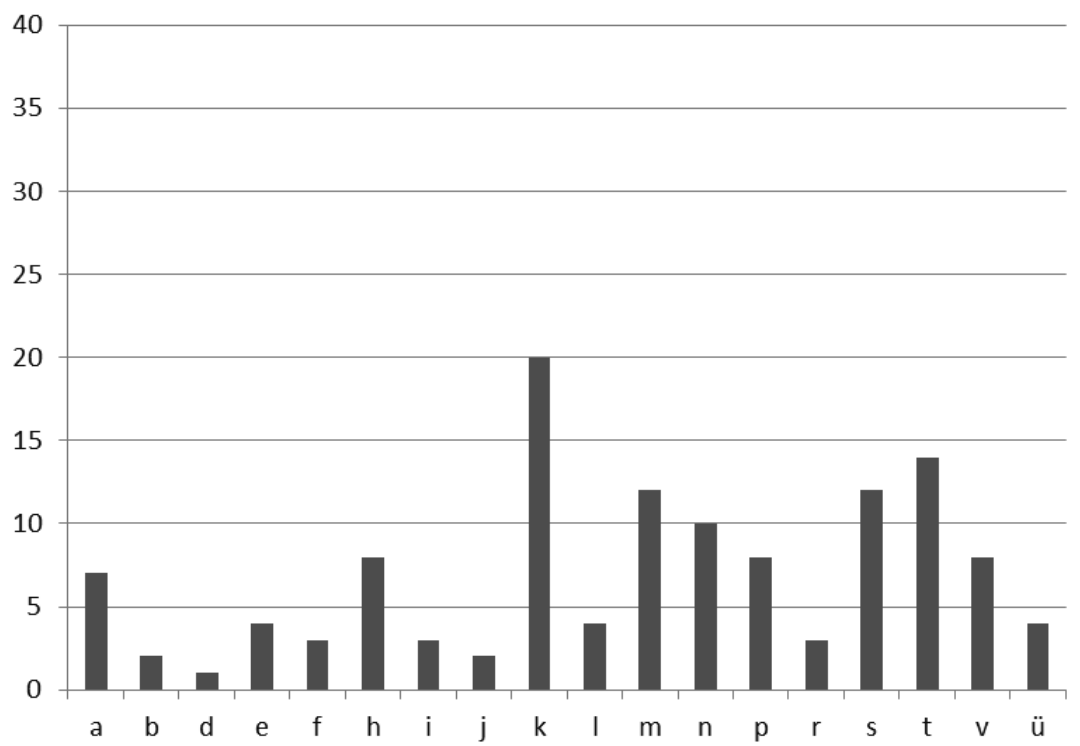

Chart 5. Different sounds in Estonian translation of Elder Edda.

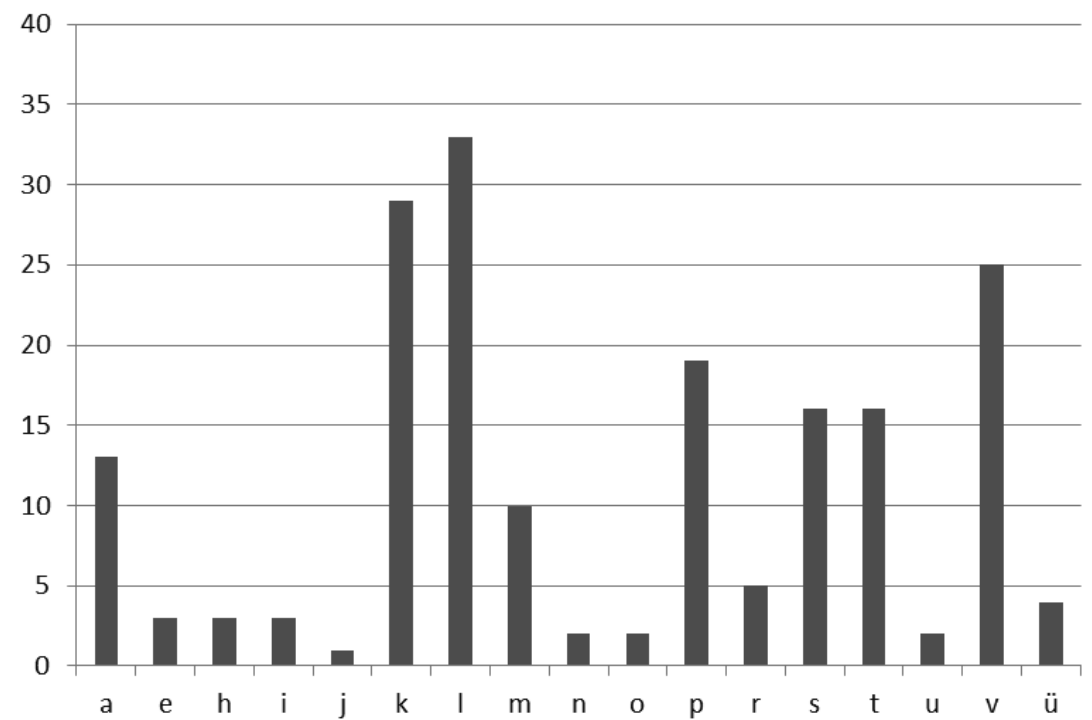

Chart 6. Different sounds in Estonian translation of Kalevala. 
Here the translation of Kalevala is somewhat different from the translation of the Germanic epics. While in Beowulf, as well as in the Elder Edda, the most frequently alliterated sound is ' $\mathrm{k}$ ', then in Kalevala it is 'l', the incidence of which in Elder Edda is, for example, less than 5\%. V-alliteration, which is the third most frequently used in the translation of Kalevala, is less frequent in the translations of Germanic verse. Also, the alliteration of ' $p$ ' is more common in Kalevala. At the same time, some sounds, like alliterated 'n' and ' $h$ ' occur in Germanic translations more often than in Kalevala. It is worth noticing that Kalevala is the only sample where alliterated ' $u$ ' occurs. We did not come across the alliterated 'ó', 'ä', 'ö' in any of our samples.

\section{Conclusions}

Alliteration plays different role in various verse traditions, being a constituent principle in some and facultative ornamental element in others. In translations, alliteration can be conveyed formally, but there are also ways to replace it with a functional equivalent. Thus, for example, Russian folk verse does not recognise alliteration as a constructive principle; its instrumentation is not charged with the metrical function, but is either euphonic or, on the contrary, semantic (paronymy, paronomasia). In translations, there may be, in a way, paradoxical consequences to its use. Some (mostly 19th-century) translators pay no attention whatsoever to alliteration or replace it with end rhyme. In the first case, the result is bylina-like blank verse (Alexandr Vostokov translated the fragments of Elder Edda into a bylina-like verse metre). In the second case, the outcome is verse which, in its formal features, does not differ from the literary canon and which has mainly just semantic connections with the original. Some 20th-century authors carefully try to convey the alliteration, following the scheme of the source text. Yet the Russian readers poorly perceive it, since such verse has no part in their tradition. In addition to that, significant differences in the structure of languages are relevant as well. Old Germanic word mostly began with a stem, the first syllable of which carried stress. Alliteration not only brings forth the stressed syllable, but is in its own way a semantic emphasis, that is, the alliterative words function as key words.

In the Estonian translations of Germanic epics, on the other hand, alliteration is commonly conveyed, since in the Estonian national epic, alliteration, too, is an important element (although not so important as in Germanic verse). Also, alliterative regisong guarantees the availability of a large amount of alliterating formulas which were also imported into literary texts and translations. 
The most common alliterative pattern in the translations of Beowulf and Elder $E d d a$ is aa, while the more complicated patterns abab and abba occur less often. In Kalevala, the pattern aabb prevails, while the more complicated patterns (cross and interlocking alliterations) are absent. The study also reveals some differences in the sound structure of alliterations: while in translations of Beowulf and Elder Edda the most common sound in alliteration is 'k', then in Kalevala it is 'l, which is quite rarely alliterated in the translations of Germanic epics. There are also sounds which are very rare in alliteration (for instance, 'õ', 'ä, ‘’’ were not alliterated in our samples).

Alliteration can not only be lost in translation, but on the contrary, its role can even be increased. For example, Russian translators, especially Altalena, saturated their texts with more alliterations than in the source text, one of the reasons being that because the Russian ear is less sensitive to alliterations, it needs stronger signals. Thus, for instance, Altalena translated these verses of Poe: And the silken sad uncertain rustling of each purple curtain / Thrilled me - filled me with fantastic terrors never felt before in the following way: Шелест шёлка, иум и шорох в мягких пурпуровых $\boldsymbol{ш т о р а х ~ - ~ / ~ Ч у т к о и ̆ , ~}$ жуткой, странной дрожью проникал меня всего. In Estonian translations sometimes there are less end rhymes, but with the compensatory strategy the number of other sound repetitions has increased, compare the same verses in the translation by Ants Oras: Kuulin, kuulen veel, $\boldsymbol{k}$ uis $\boldsymbol{k}$ ahin, siidi hiiliv salasahin / esiriideist käib, ja vaatan, hurmund, hirmund surmani. ${ }^{5}$

\section{References}

Audova, Iris 1995. Algriim vadja rahvalauludes. Tartu: Department of Estonian Philology [Unpublished dissertation. Manuscript in the University of Tartu Library].

Čiževsky, Dmitry 1949. On Alliteration in Ancient Russian Epic Literature. In: Jakobson, Roman; Simmons, Ernest J. (eds.), Russian Epic Studies (Memoirs of the American Folklore Society 42). Philadelphia: American Folklore Society, 125-130.

Ellinger, Florence Karn 1938. Alliteration in Selected Plays of Plautus. Ohio State University.

\footnotetext{
5 This research was supported by grant no IUT20-1. The preliminary version of this paper was presented at the conference "Alliterativa Causa" (January 18-19, 2013, London). The authors are grateful to Igor Pilshchikov for the careful reading and useful suggestions.
} 
Friedberg, Maurice 1997. Literary Translation in Russia: A Cultural History. University Park: Pennsylvania State University Press.

Frog; Stepanova, Eila 2011. Alliteration in (Balto-)Finnic Languages. In: Roper, Jonathan (ed.), Alliteration in Culture. Houndmills: Palgrave MacMillan, 195-218.

Harvilahti, Lauri 2000. Altai Oral Epic. In: Oral Tradition 15/2, 215-229.

Kuryłowicz, Jerzy 1949. Latin and Germanic Metre. In: English and Germanic Studies 2, 37-42.

Kuryłowicz, Jerzy 1970. Die sprachlichen Grundlagen der altgermanischen Metrik. (Innsbrucker Beiträge zur Sprachwissenschaft 1). Innsbruck: Institut für Vergleichende Sprachwissenschaft der Universität Innsbruck.

Kuryłowicz, Jerzy 1975. Metrik und Sprachgeschichte. Wrocław etc.: Zakład Narodowy im. Ossolińskich.

Kuusi, Matti 1953. Kalevalaisen runon alkusointuisuudesta. In: Virittäjä 2, 198-207.

Langer, Kenneth 1978. Some Suggestive Uses of Alliteration in Sanskrit Court Poetry. In: Journal of the American Oriental Society 98(4), 438-445.

Laugaste, Eduard 1962. Eesti alliteratsioonist ja assonantsist. In: Keel ja Kirjandus 9, 531-537.

Laugaste, Eduard 1969. Sõnaalguline ja sisealliteratsioon eesti rahvalauludes. Eesti rahvalaulu struktuur ja kujundid I (TRÜ Toimetised 234). Tartu: Tartu Riiklik Ülikool.

Lehmann, Winfred P. 1956. The Development of Germanic Verse Form. Austin: University of Texas Press and Linguistic Society of America.

Lehmann, Winfred P. 1972. Germanic. In: Wimsatt William K. (ed.), Versification: Major Language Types. New York: New York University Press.

Leino, Pentti 1970. Alliteratsioon ja regivärsiline rahvalaul. In: Keel ja Kirjandus 8, 504-507.

Levin, Theodore C.; Edgerton, Michael E. 1999. The Throat Singers of Tuva. In: Scientific American 281(3), 80-87.

Lotman, Mihhail 1998. Värsisüsteemidest (peamiselt vene ja eesti värsi näitel). In: Akadeemia 9, 1846-1874; 10, 2058-2078.

Lotman, Mihhail; Nakhimovsky, Alexander 1971. Ob odnom stikhotvorenii N. A. Zabolockogo. In: Rudnev, Pjotr (ed.), Russkaja filologija 3, Tartu: Tartu Riiklik Ülikool, 62-75. 
Petrov, Nikolaj Egorovich 1990. Khorovodnye pesni osuokhaj kak zhanr jakutskogo fol'klora. In: Sovetskaja tjurkologija 5, 7-12.

Roper, Jonathan 2009. On Finnic and English alliterative metres. In: Kilpiö, Matti; Kahlas-Tarkka, Leena (eds.), Anglo-Saxons and the North: Essays Reflecting the Theme of the 10th Meeting of the International Society of Anglo-Saxonists in Helsinki, August 2001. Tempe, Ariz.: Arizona Center for Medieval and Renaissance Studies, 89-108.

Sievers, Eduard 1893. Altgermanische Metrik. Sammlung kurzer Grammatiken germanischer Dialekte. Halle: Niemeyer.

Smirnickaja, Ol'ga Aleksandrovna 1994. Stikh i jazyk drevnegermanskoj pojezii. Moskva: Filologija.

Stebleva, Ija Vasil'evna 1965. Poezija tjurkov VI-VIII vekov. Moskva: Nauka.

Stebleva, Ija Vasil'evna 1971. Proishozhdenie i razvitie tjurkskoj alliteracionnoj sistemy v svjazi s istoricheskim rodstvom tjurkskikh i mongol'skikh jazykov. In: Sovetskaja tjurkologija 6, 80-84.

Steinitz, Wolfgang 1934. Der Parallelismus in der finnisch-karelischen Volkdichtung. Helsinki: Suomalainen tiedeakatemia.

Terasawa, Jun 2011. Old English Meter: An Introduction. Toronto: University of Toronto Press.

Taranovsky, Kiril 1965a. 'Süsse' und 'feuchte' Reime bei Lermontov. In: Zeitschrift für slavische Philologie 32, 251-254.

Taranovsky, Kiril 1965b. The Sound Texture of Russian Verse in the Light of Phonemic Distinctive Features. In: International Journal of Slavic Linguistics and Poetics 9, 114-124.

Zhirmunsky, Victor Maksimovich 1964. Ritmiko-sintaksicheskij parallelizm kak osnova drevnetjurkskogo narodnogo epicheskogo stikha. In: Voprosy jazykoznanija 4, 3-24.

Zhirmunsky, Victor Maksimovich 1968. O nekotorykh problemah teorii tjurkskogo narodnogo stikha. In: Voprosy jazykoznanija 1, 23-42.

Zhirmunsky, Victor Maksimovich 1974. Tjurkskij geroicheskij epos. Leningrad: Nauka. 


\section{Addendum.}

\section{Transliterations of Russian translations of Poe's Raven}

Kak-to v polnoch', v chas ugrjumyj, polnyj tjagostnoju dumoj, Nad starinnymi tomami ja sklonjalsja v polusne, Grjozam strannym otdavalsja, vdrug nejasnyj zvuk razdalsja, Budto kto-to postuchalsja - postuchalsja v dver' ko mne. “Jeto verno”, prosheptal ja, „gost' v polnochnoj tishine, Gost' stuchitsja v dver' ko mene”.

Jasno pomnju... Ozhidan'ja... Pozdnej oseni rydan'ja... I v kamine ochertan'ja tusklo tlejushhih uglej... O, kak $\boldsymbol{z h}$ azhdal ja rassveta, kak ja tshhjotno $\boldsymbol{z h}$ dal otveta Na stradan'e, bez priveta, na vopros o nej, o nej, O Lenore, chto blistala jarche vseh zemnyh ognej, O svetile prezhnih dnej.

I zaves purpurnyh trepet izdaval kak budto lepet, Trepet, lepet, napolnjavshij tjomnym chuvstvom serdce mne. Neponjatnyj strah smirjaja, vstal ja s mesta, povtorjaja: “Jeto tol'ko gost', bluzhdaja, postuchalsja v dver' ko mne, Pozdnij gost' prijuta prosit v polunochnoj tishine Gost' stuchitsja v dver' ko mne".

(Edgar Allan Poe's Voron, translated by Konstantin Balmont, 1894)

Kak-to v polnoch', utomljonnyj, ja zabylsja, polusonnyj, Nad tainstvennym znachen'em folianta odnogo; Ja dremal, i vsjo molchalo... Chto-to tiho prozvuchalo Chto-to tiho zastuchalo u poroga moego.

Ja podumal: "To stuchitsja gost' u vhoda moego Gost', i bol'she nichego".

Pomnju vsjo, kak jeto bylo: mrak - dekabr' - nenast'e vylo Gas ochag moj - tak unylo padal otblesk ot nego... Ne svetalo... Chto za $\boldsymbol{m}$ uki! Ne $\boldsymbol{m}$ ogla $\boldsymbol{m}$ ne glub' nauki Dat' zabven'e o razluke s devoj serdca moego, O Lenore, vzjatoj v Nebo proch' iz doma moego, Ne ostaviv nichego... 
Shelest shjolka, shum i shoroh v mjagkih purpurovyh shtorah -

Chutkoj, zhutkoj, strannoj drozh'ju pronikal menja vsego;

I, smirjaja strah minutnyj, ja shepnul v trevoge smutnoj:

“To stuchitsja besprijutnyj gost' u vhoda moego -

Pozdnij putnik tam stuchitsja u poroga moego -

Gost', i bol'she nichego".

(Edgar Allan Poe's Voron, translated by Altalena, 1897)

Kak-to v polnoch', v chas unylyj, ja vnikal, ustav, bez sily,

Mezh tomov starinnyh, v stroki rassuzhden'ja odnogo

Po otvergnutoj nauke, i rasslyshal smutno zvuki,

Vdrug u dveri slovno stuki, - stuk u vhoda moego.

"Jeto - gost', - probormotal ja, - tam, u vhoda moego.

Gost', - i bol'she nichego!"

Ah! mne pomnitsja tak jasno: byl dekabr' i den' nenastnyj,

Byl kak prizrak - otsvet krasnyj ot kamina moego.

Zhdal zari ja v neterpen'i, v knigah tshhetno uteshen'e

Ja iskal v tu noch' muchen'ja, - bden'ja noch', bez toj, kogo

Zvali zdes' Linor. To imja... Shepchut angely ego,

$\mathrm{Na}$ zemle zhe - net ego.

Shelkovistyj i ne rezkij, shoroh aloj zanaveski

Muchil, polnil temnym strahom, chto ne znal ja do togo.

Chtob smirit' v sebe bien'ja serdca, dolgo v uteshen'e

Ja tverdil: “To - poseshhen'e prosto druga odnogo.»

Povtorjal: «To - poseshhen'e prosto druga odnogo,

Druga, - bol'she nichego!"

(Edgar Allan Poe's Voron, translated by Valery Bryusov, 1905) 